Papers and Proceedings of the Royal Society of Tasmania, Volume 114, 1980. (ms. received $17.5 \cdot 1979$ )

\title{
LATE MIDDLE CAMBRIAN FOSSILS FROM BEACONSFIELD, TASMANIA
}

$$
\text { by J.B. Jago }
$$

School of Applied Geology, South Australian Institute of Technology

\author{
(with one plate)
}

\section{ABSTRACT}

JAGO, J.B., 1980 ( $31 \mathrm{v}$ ): Late Middle Cambrian fossils from Beaconsfield, Tasmania. Pap. Proe. R. Soc. Tasm., 1l4: 219-233 (incl. one plate). ISSN 0080-4703. School of Applied Geology, South Australian Institute of Technology, Ingle Farm, South Australia, Australia.

The only known Cambrian fauna of the Beaconsfield Trough has a late Middle cambrian (Ptychagnostus nathorsti or Lejopyge Zaevigata zone) age; it occurs $4.5 \mathrm{~km}$ south-west of Beaconsfield, northern Tasmania. The poorly preserved fauna includes an orthid brachiopod, plus the trilobites Nepea sp., cf. Erediaspis sp., a probable member of the Damesellidae, a possible solenopleurid, agnostoids and some fragmentary material. The fauna occurs about 140m below the contact with the overlying Tremadocian or Arenigian Cabbage Tree Formation, which suggests that most, if not all, of the Late Cambrian is not represented in the Beaconsfield area.

\section{INTRODUCTION}

The purpose of this note is to record the late Middle Cambrian fauna of the "Dally's Siltstone" near Beaconsfield, northern Tasmania. This fauna is important as it is the only Cambrian fauna known from the Beaconsfield Trough (see Williams 1978 for palaeotectonic details). Green (1959) discovered Cambrian fossils $4.5 \mathrm{~km}$ SW of Beaconsfield at 1at. $41^{\circ} 14.4^{\prime} \mathrm{S}$, 1ong. $146^{\circ} 51.0^{\prime} \mathrm{E}$ in what he termed the Dally's Siltstone. Opik in Green recorded the possible presence of Dresbachia and suggested a late Middle or early Late Cambrian age. Öpik (1967, p.32) recorded Erediaspis from this fauna and suggested a Mindyallan age. Gee and Legge (1974) reinterpreted the geology of the Beaconsfield area and suggested that the Cambrian rocks outcrop in a series of fault slices. The position of the fossil locality is shown on the Beaconsfield map sheet. The locality in question occurs in what Gee and Legge termed the Middle Arm Creek Slice. As noted in Gee and Legge (p.24) the lithology of the fossil locality is essentially a slaty siltstone with thin interbeds of sandstone. Within the fossiliferous horizons there are a few layers of quartz pebbles up to $8 \mathrm{~mm}$ across. These pebbles are not particularly well rounded thus suggesting a short transport history. With one exception, all the fossils are disarticulated. The fossils tend to occur concentrated in distinct layers indicating that they represent current concentrated material. The best preserved fossils occur withon one of the thicker sandstone interbeds. However, most of the specimens are very poorly preserved, particularly those found in the siltstone.

The fossils figured herein occur about 140 metres below the contact of the Cambrian rocks with the overlying Cabbage Tree Formation. Some $2 \mathrm{~km}$ further to the north-west, the Cabbage Tree Formation contains late Tremadocian or very early Arenigian fossils (Banks and Burrett, in press). This suggests that most, if not all, of the Late Cambrian is not represented in the Beaconsfield area. Jago (1973) has discussed details of similar "Cambro-Ordovician" contacts elsewhere in Tasmania

The known fauna is limited to a single specimen of an orthid brachiopod, plus the following trilobites which are illustrated in this note: Nepea sp., cf. Erediaspis sp., a probable member of the Damesellidae, a possible solenopleurid, two and possibly three agnostoid species plus a few fragments. The presence of Nepea is important because in Queensland, Nepea is known only from the late Middle Cambrian Ptychagnostus nathorsti 
and Lejopyge Laevigata Zones (Opik 1970). The species described by Opik (1970) as Nepea sp. NC from the Ptychagnostus gibbus Zone does not belong in Nepea.

None of the species are preserved well enough to warrant description. Hence, only some representative photographs and brief remarks are given for each species. All catalogue numbers refer to the collection of the Geology Department, University of Tasmania.

Phylum BRACHIOPODA Dumeril, 1806

Class ARTICULATA Huxley, 1869

Order ORTHIDA Schuchert and Cooper, 1932

$$
\begin{aligned}
& \text { ORTHIDA, gen. et sp. idet } \\
& \text { (p1.1, fig. 1) }
\end{aligned}
$$

One poorly preserved specimen of an orthid brachiopod is known from Beaconsfield.

Class TRILOBITA Walch, 1771

Order MIOMERA Jaekel, 1909

Superfamily AGNOSTACEA M'Coy, 1849

(p1.1, figs. 2-4)

Three very poorly preserved agnostoid cephala and two similarly preserved pygidia are available. The preservation is such that no generic assignments can be made. However, at least two species seem to be represented because the two figured cephala (p1.1., figs 2 \& 3 ) appear to be different.

The cephalon figures in pl.1, fig. 2 has an angular glabellar posterior and a well rounded glabellar anterior; the cephalon figured in pl.1., fig. 3, appears to have a rounded glabellar posterior and a narrow glabellar anterior. The pygidium (p1.1, fig. 4) which occurs on the same specimen as the cephalon figured in p1.1, fig. 3, may belong to either of the cephala or to a third species.

\section{Order PTYCHOPARIIDA Swinnerton, 1915 \\ Family SOLENOPLEURIDAE Angelin, 1854 \\ SOLENOPLEURIDAE, gen. et sp. indet.}

(pl.1, figs 10-16)

The most common trilobite species from Beaconsfield is represented by about twelve cranidia, several free cheeks and three pygidia. It is likely that the rostrum figured inpl. I,fig. 14 belongs in this species. If the very poorly preserved complete specimen (p1.1, fig. 11) is of the same species, then there are at least twelve thoracic segments. This species appears to be affiliated with the Solenopleuridae.

\section{Family TRICREPICEPHALIDAE Palmer, 1954} Genus EREDIASPIS Öpik, 1967

$$
\begin{gathered}
\text { cf. Erediaspis sp. } \\
\text { (p1.1, figs 7-9) }
\end{gathered}
$$

The best preserved specimen (UT 92677) from Beaconsfield is an almost complete cranidium, which is similar to that of Erediaspis eretes Opik. The major difference is the presence of a plectrum on the Beaconsfield specimen. 


\section{J.B. Jago}

Family DAMESELLIDAE Kobayashi, 1935

DAMESELLIDAE, gen. et sp. indet (p1.1, fig. 21)

The very poorly preserved spinose pydigium, UT 98241a, probably belongs in Damesezla, BlackweZderia, or a related genus of the Damesellidae.

Family NEPEIDAE Whitehouse, 1939

Genus NEPEA Whitehouse, 1939

$$
\begin{gathered}
\text { Nepea sp. } \\
\text { (p1. 1, figs 5-6) }
\end{gathered}
$$

Two partial cranidia (UT 50215 and UT 98235) are available. They clearly belong to Nepea but the preservation is such that no species assignation can be given.

$$
\begin{gathered}
\text { TRILOBITA INCERTAE SEDIS } \\
(\mathrm{p} 1.1, \text { figs } 17-20)
\end{gathered}
$$

These four very poorly preserved specimens may belong in four different species, but it is possible that the thoracic segment ( 1.1 fig. 18) may be of the same species as the cranidium figured as p1.1, fig. 19.

\section{ACKNOWLEDGEMENTS}

This work was supported by a grant from the Australian Research Grants Committee (E72/15101). Dr. B. Daily (University of Adelaide) helped collect the specimens. Dr. M.R. Banks and Mrs. P. Green (University of Tasmania) arranged the cataloguing of the specimens.

\section{REFERENCES}

Banks, M.R. and Burrett, C., 1980: A preliminary Ordovician biostratigraphy of Tasmania. J. geol. Soc. Aust., 26: 363-375.

Gee, R.D. and Legge, P.J., 1974: Beaconsfield. Explan. Rep. geol. Surv. Tasm., one mile geological map series, $8215 \mathrm{~N}$.

Green, D.H., 1959: Geology of the Beaconsfield district, including the Anderson's Creek Ultramafic complex. Ree. Queen Vict. Mus. Tasm. 10.

Jago, J.B., 1973: Paraconformable contacts between Cambrian and Junee Group sediments in Tasmania. J. geol. Soc. Aust., $20: 373-377$.

Öpik, A.A., 1967: The Mindyallan Fauna of north-western queensland. Bulz. Bur. Miner. Resour. Geol. Geophys. Aust., 74.

, 1970 : Nepeid trilobites of the Middle Cambrian of northern Australia. Ibid., 113.

Williams, E., 1978: Tasman Fold Belt system in Tasmania. Tectonophysies, 48 : $159-205$. 
Fig. 1. Orthida, gen et sp. indet., UT 98231a, internal mould, X3.

Figs 2-4. Agnostacea

2. UT 98234, internal mould of cephalon, X5.5

3. UT 98231a, internal mould of cephalon, $X 8$.

4. UT 98231a, internal mould of pygidium, X4.

Figs 5-6. Nepea sp.

5. UT 98235, internal mould of cranidium, $X 4.3$

6. UT 50215, external mould of cranidium, X6.

Figs 7-9 cf. Erediaspis sp.

7. UT 92677, external mould of cranidium, $\times 2.9$.

8,9 UT 92677, internal mould of cranidium (counterpart of fig. 7), 8, x 2.3; 9 , front view, $\times 2.7$.

Figs 10-16 Solenopleuridae, gen et sp. indet.

10. UT 98236 a, internal mould of cranidium, $\mathrm{X} 2.5$.

11. UT 29073, internal mould of very poorly preserved, almost complete specimen, $\mathrm{X} 1.5$

12. UT 98237 , externa1 mould of cranidium, $\mathrm{X} 5$.

13. UT 98238a, internal mould of pydidium, X4

14. UT 98239a, internal mould of rostrum, $\mathrm{X} 4$.

15. UT 98233b, external mould of 1ibrigena, $\mathrm{X} 2.6$.

16. UT 98233a, interna1 mould of librigena, (counterpart of fig 15), X2.4.

Figs 17-20 Trilobita Incertae sedis

17. UT 98244, internal mould of cranidium, X4

18. UT 29073a, internal mould of very poorly preserved thoracic segment, X1.

19. UT 98232a, internal mould of cranidiun, X1.5.

20. UT 98240, internal mould of pygidium, X4.5.

Fig. 21 Dameselidae, gen. et sp. indet., UT 98241a, internal mould of pygidium, $\times 2$

A11 specimens were whitened with magnesium oxide prior to photography. The brachiopod and all external moulds of trilobites are rubber casts. 

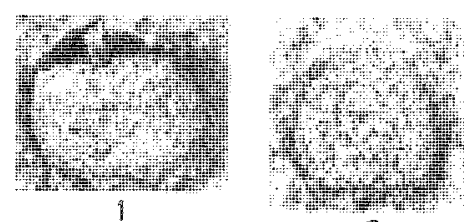

2

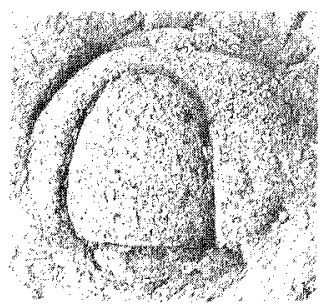

7

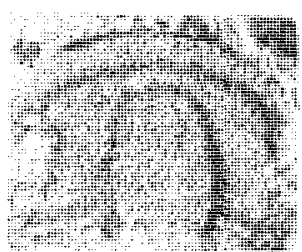

10

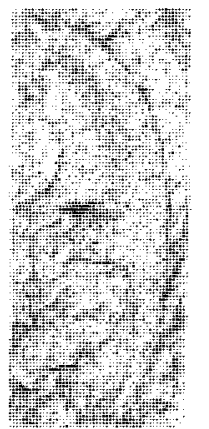

15
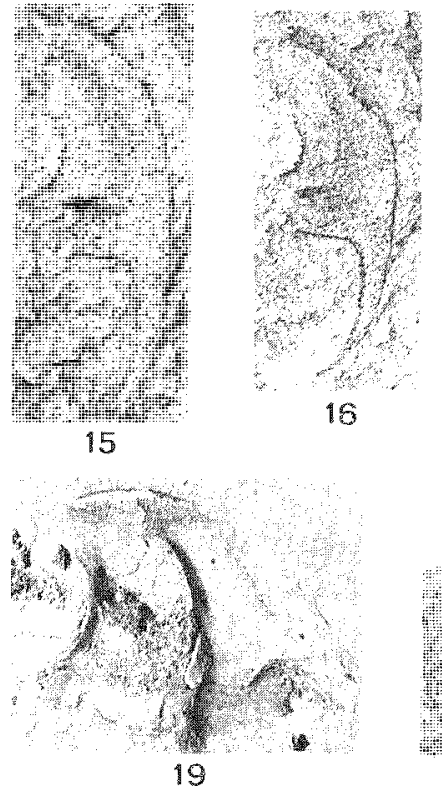

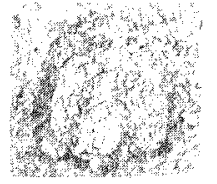

3
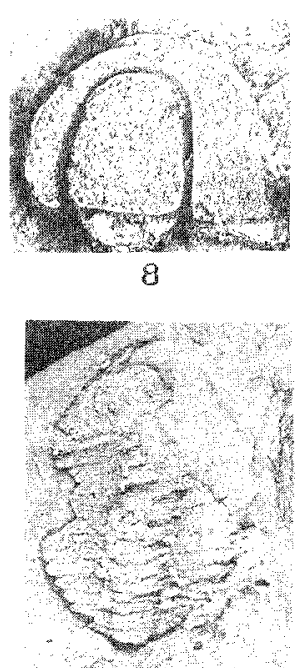

11
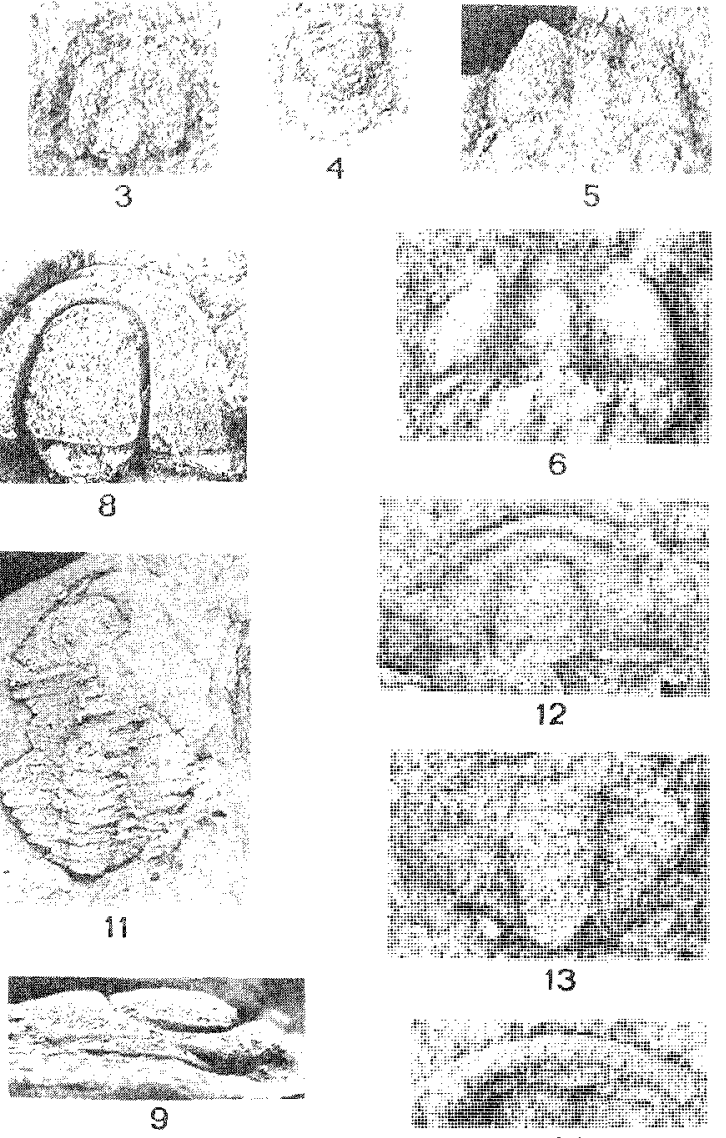

5
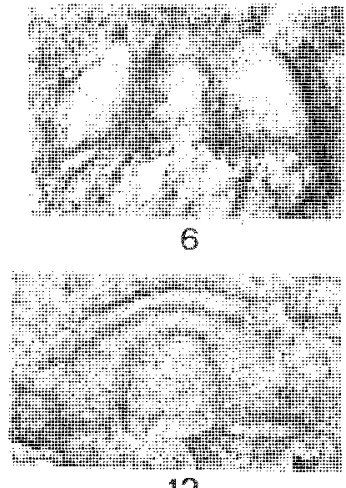

12

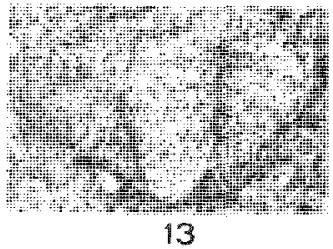

$4 p+4+4+4$

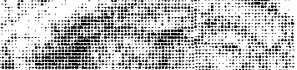

14

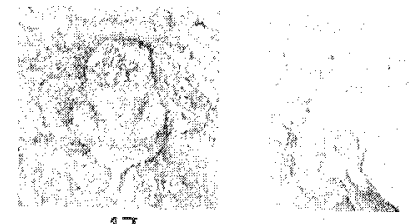

17

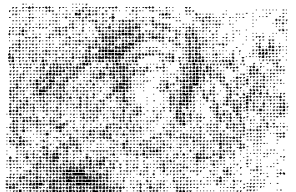

20

PLATE 1 .

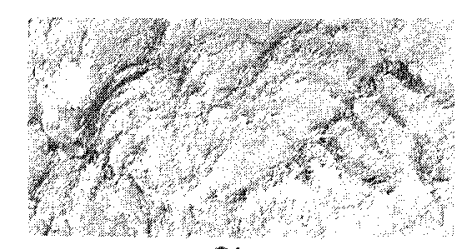

21

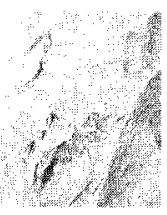

18 